\title{
A RARE CASE OF ADRENAL PHEOCHROMOCYTOMA WITH UNUSUAL CLINICAL AND BIOCHEMICAL PRESENTATION: A CASE REPORT AND LITERATURE REVIEW
}

\author{
MUNSHI AKID MOSTOFA ${ }^{1}$, AKM SHAHADAT HOSSAIN ${ }^{2}$, HAFIZ-AL-ASAD ${ }^{3}$, MD. MAHFUZUR RAHMAN \\ CHOWDHURY ${ }^{3}$, LUTFUL HASAN ${ }^{4}$
}

\begin{abstract}
A 45 years old male, nondiabetic, hypertensive, nonasthmatic, nonsmoker, farmer from Pabna presented with the complaints of pain over right hypochondrium for 4 months andalso gave history of significant weight loss of about $15 \mathrm{~kg}$ in the last 6 months. He also developed bilateral gynecomastia for 2 years. On examination, Blood pressure was $200 / 100 \mathrm{~mm}$ of $\mathrm{Hg}$ and bilateral gynecomastia were present.Both testes were mildly atrophied.Systemicexamination revealed mild tenderness in right hypochondrium on deep palpation of abdomen. USG of W/A revealed A heterogenous mixed echogenic mass $\left(9.9^{\star} 8.9\right)$ was seen in upper polar region of right kidney. Suggestive of Right suprarenal mass. CT scan W/A with contrast showed heterogenous contrast enhancing well defined rounded soft tissue density lesion measuring about $90 * 86 \mathrm{~mm}$ was noted in right adrenal region which revealed a right adrenal mass consistent with adrenal pheochromocytoma. However,clinical biochemistry tests revealed normal levels of plasma catecholamines (dopamine, norepinephrine, and epinephrine) and metanephrine, which are unusual findings in adrenal pheochromocytoma. Serum Aldosterone,Basal cortisol, Renin in plasma, ACTH and 24 hours Urinary Free cortisol were normal.Meanwhile, The patient had persistent hypokalemia and serum Testosterone, LH and FSH were below normal level. Open right adrenalectomy was done. Histopathology and immunohistochemistryconfirmed the diagnosis of adrenal pheochromocytoma. Following surgery, the patient did well and showed full recovery at follow-up after one month. To our knowledge, this is the first report in Dhaka Medical college hospital of the extremely rare entity of pheochromocytoma with an unusual clinical and biochemical scenario.
\end{abstract}

Bangladesh J. Urol. 2018; 21(2): 168-171

\section{Background}

Pheochromocytoma is a rare but life-threatening condition that has varied clinical presentations particularly hypertension, headache, palpitation, and sweating. ${ }^{1,2}$ Patients with suggestive clinical features

1. MS Urology Final Student

2. Professor, Department of Urology, Dhaka Medical College

3. Assistant Professor, Department of Urology, Dhaka Medical College

4. Assistant Registrar, Department of Urology, Dhaka Medical College Hospital

Correspondences: Munshi Akid Mostofa, Department of Urology, Dhaka Medical College Hospital

Received: 9 August 2017

Accepted: 05 March 2018 are frequently tested for pheochromocytoma. The medical interest in this tumor has increased with the improved availability of diagnostic laboratory tools particularly plasma or urinary fractionated metanephrines (metanephrine and normetanephrine), and other neuroendocrine markers particularly chromogranin A. ${ }^{3,4}$ The wide universal availability of different imaging facilities, both anatomical and functional, has also improved the detection of pheochromocytoma. ${ }^{5}$

The growing awareness for implementing different protocols and guidelines that consider 
pheochromocytoma in the work-up and differential diagnosis has improved diagnosis of the disorder. ${ }^{6}$ Accurate diagnosis is important because if the tumor is detected early laparoscopic or surgical treatment is usually curative before other changes or complications take place.

Catecholamine-producing tumors are neuroendocrine tumors that affect the chromaffin cells of adrenal medulla and postganglionic fibers of the sympathetic nervous system. ${ }^{1,2}$ These tumors are characterized by the synthesis, storage, release, and secretion of catecholamines and their metabolites. They include pheochromocytomas in the adrenal medulla and paragangliomas in the extra-adrenal sympathetic ganglions usually below the diaphragm in the retroperitoneum or organ of Zuckerkandl and various sites including the head, neck, thorax, and abdomen. However, although the majority of these tumors are benign and adrenal, investigation workup should consider their tendency for being multiple, malignant, and familial with genetic pathogenesis. $^{7}$

Epinephrine (and its metabolite metanephrine) is the catecholamine that is produced exclusively by the adrenal medulla and adrenal pheochromocytoma. On the other hand, norepinephrine (and its metabolite normetanephrine) is the catecholamine produced by the adrenal medulla and adrenal pheochromocytoma as well as by the extra-adrenal pheochromocytoma and paraganglioma, which can also produce dopamine and its metabolite methoxytyramine. However, this is rare. ${ }^{8}$

Pheochromocytomas can affect individuals of all ages. They are common in people aged between 40 and 50 years, and relatively more common among females. Adrenal pheochromocytomas constitute nearly $85 \%$ of cases of pheochromocytomas, with $15 \%$ being extraadrenal paragangliomas that affect the sympathetic ganglions anywhere from the base of the brain to the urinary bladder. ${ }^{1,2}$ Laboratory diagnosis is usually achieved by measuring the catecholamines, or more importantly their metabolites in plasma or urine. Although different markers, including catecholamines and vanillylmandelic acid, are utilized as diagnostic tests, total and fractionated metanephrines in plasma or urine provide the best valid laboratory test for excluding or confirming pheochromocytoma. ${ }^{2,9}$ In addition, chromogranin $\mathrm{A}$ is another reliable marker for neuroendocrine tumors, including pheochromocytoma and is increasingly used in the diagnostic workup and follow-up of patients with these tumors. ${ }^{4}$ Following diagnosis, removal of the adrenal gland or the tumor is done by open surgery or by the laparoscopic technique, which is considered the 'gold standard' treatment choice since $1992 .{ }^{10-12}$

\section{Case Report}

Mr. Jasim Uddin, 45 years male, nondiabetic, hypertensive, nonasthmatic, nonsmoker, farmer from Pabna presented with the complaints of pain over right hypochondrium for 4 months which was dull aching in nature, non-radiating, aggravated by physical work but relived by taking analgesics and he had never had a pain like this before. Pain was not associated with fever with chills and rigor. He also gave history of significant weight loss of about $15 \mathrm{~kg}$ in the last 6 months. He also developed bilateral gynecomastia for 2 years. There was no evening rise of temp, night sweat, cough, hemoptysis, chest pain or bone pain. His bowel habit was normal.

On examination, Patient was anxious, mildly anemic. pulse $60 \mathrm{~b} / \mathrm{m}$, bp180/100 $\mathrm{mm}$ of $\mathrm{Hg}$ and bilateral gynecomastia were present which were symmetrically enlarged, nipple and areola were normal, on palpation, firm breast disc palpable on both sides which were mobile, free from skin and the underlying pectoral muscle. Both testes were mildly atrophied. Systemic examination reveals no abnormality but only mild tenderness in right hypochondrium on deep palpation of abdomen. Digital rectal examination was normal.

On investigation, $\mathrm{Hb} 12.3 \%$, S creatinine 1.42 mg/dl. Urine R/M/E normal. USG of W/A revealedboth kidneys were normal. A heterogenous mixed echogenic mass $\left(9.9^{*} 8.9\right)$ was seen in upper polar region of right kidney. Suggestive of Right suprarenal mass. CT scan W/A with contrast showed heterogenous contrast enhancing well defined rounded soft tissue density lesion measuring about $90 * 86 \mathrm{~mm}$ was noted in right adrenal region which push right kidney downward. The mass was also separated from liver. 

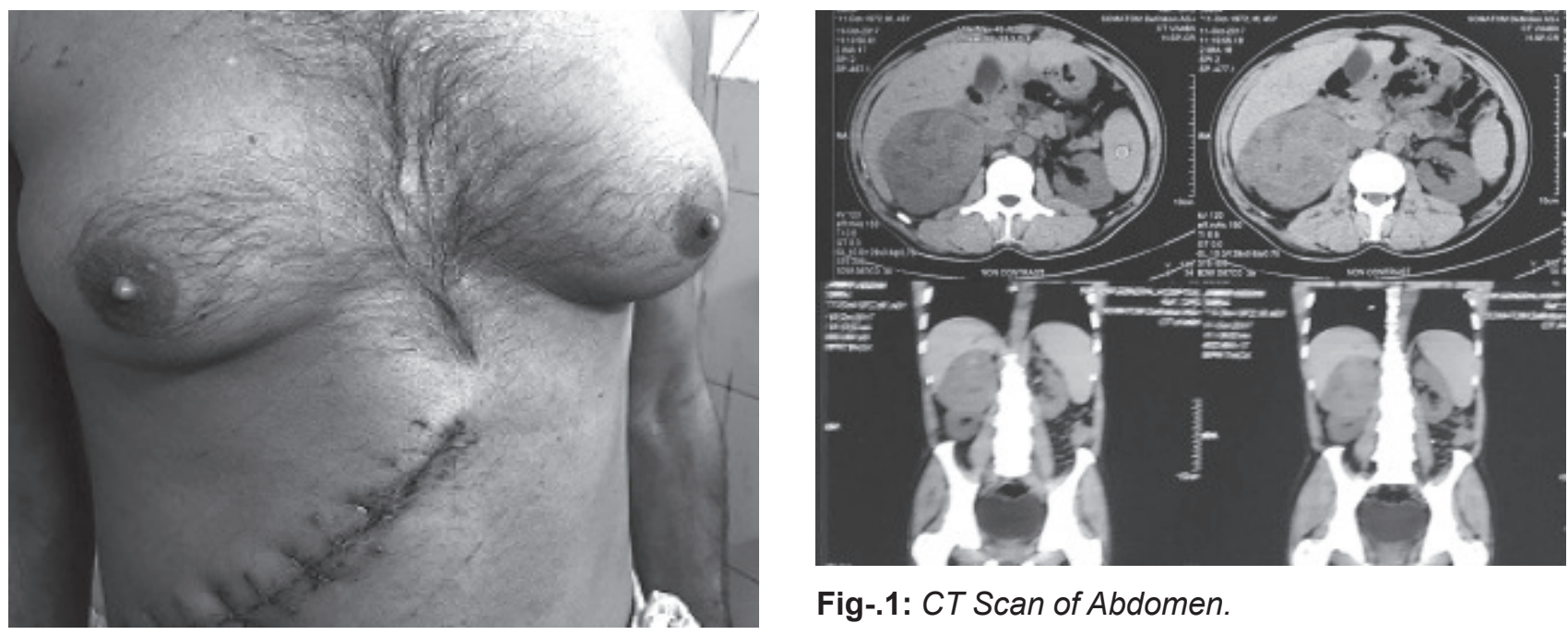

Fig-.1: CT Scan of Abdomen.

Table-I

Laboratory test

\begin{tabular}{lll}
\hline Test Name & Result Unit & \multicolumn{1}{c}{ Ref } \\
\hline S. Aldosterone & $169 \mathrm{pg} / \mathrm{ml}$ & $20-180 \mathrm{pg} / \mathrm{ml}$ \\
Basal cortisol & $70.74 \mathrm{nmol} / \mathrm{l}$ & $100-690 \mathrm{pg} / \mathrm{ml}$ \\
ACTH & $7.07 \mathrm{pg} / \mathrm{ml}$, & $8.1-57.8 \mathrm{pg} / \mathrm{ml}$ \\
Epinephrine & $82.23 \mathrm{pg} / \mathrm{ml}$, & $125 \mathrm{pg} / \mathrm{ml}$ \\
Nonepinephrine & $245 \mathrm{pg} / \mathrm{ml}$ & $600 \mathrm{pg} / \mathrm{ml}$ \\
Renin in plasma & $14.70 \mathrm{pg} / \mathrm{ml}$ & $4-37 \mathrm{pg} / \mathrm{ml}$ \\
24 hours Metanephrine in urine & $1656.23 \mathrm{nmol} / \mathrm{day}$ & $<1775 \mathrm{nmol} / \mathrm{day}$ \\
24 hours Urinary Free cortisol & $195 \mathrm{ug} / 24 \mathrm{hours}$ & $50-190 \mathrm{ug} / 24 \mathrm{hours}$ \\
Testosterone & $1.38 \mathrm{ng} / \mathrm{ml}$. & $2.80-14 \mathrm{ng} / \mathrm{ml}$ \\
LH & $0.09 \mathrm{mlU} / \mathrm{ml}$ & $0.57-11.95 \mathrm{ng} / \mathrm{ml}$ \\
FSH & $0.20 \mathrm{mlU} / \mathrm{ml}$ & $0.95-1195 \mathrm{mlU} / \mathrm{ml}$ \\
S Potassium & $2.9 \mathrm{mmol} / \mathrm{l}$ & $3.5-5.1 \mathrm{~m} \mathrm{~mol} / /$ \\
Vitamin D & $25.2 \mathrm{ng} / \mathrm{ml}$ & $30-100 \mathrm{ng} / \mathrm{ml}$ \\
TSH & $4.35 \mathrm{ulU} / \mathrm{ml}$ & $0.47-5.01 \mathrm{ulU} / \mathrm{ml}$ \\
S Magnesium & $0.6 \mathrm{mmol} / \mathrm{l}$ & $0.7-1.05 \mathrm{nmol} / \mathrm{l}$ \\
S Albumin & $27.2 \mathrm{gm} / \mathrm{l}$ & $34-50 \mathrm{gm} / \mathrm{l}$ \\
\hline
\end{tabular}

Diagnosis: Right Adrenal mass with hypertension with hypokalemia with gynecomastia with testicular atrophy with secondary hypogonadism.Open right adrenalectomy was performed. There was some blood loss that necessitated one unit of packed red blood cells (RBC) transfusion. The adrenal tumor was excised. The patient did well and remained normotensive in the postoperative period. Histopathology and immunohistochemistry confirmed the diagnosis of adrenal pheochromocytoma. She was discharged after eight days withoutcomplaint and with normal neuroendocrine markers. She refused genetic testing.

\section{References}

1. Manger WM, Gifford RW. Pheochromocytoma. J Clin Hypertens (Greenwich) 2002 Jan-Feb; 4(1):62-72. 
2. Lenders JW, Eisenhofer G, Mannelli M, Pacak K. Phaeochromocytoma. Lancet 2005 Aug;366(9486):665- 675.

3. Lenders JW, Pacak K, Walther MM, Linehan WM, Mannelli M, Friberg P, et al. Biochemical diagnosis of pheochromocytoma: which test is best? JAMA 2002 Mar;287(11):1427-1434.

4. Grossrubatscher E, Dalino P, Vignati F, Gambacorta M, Pugliese R, Boniardi M, et al. The role of chromogranin $A$ in the management of patients with phaeochromocytoma. Clin Endocrinol (Oxf ) 2006 Sep;65(3):287-293.

5. Havekes B, King K, Lai EW, Romijn JA, Corssmit EP, Pacak K. New imaging approaches to phaeochromocytomas and paragangliomas. Clin Endocrinol (Oxf ) 2010 Feb; 72(2):137-145.

6. Pacak K, Eisenhofer G, Ahlman H, Bornstein SR, Gimenez-Roqueplo AP, Grossman AB, et al; International Symposium on Pheochromocytoma. Pheochromocytoma: recommendations for clinical practice from the First International Symposium. October 2005. Nat Clin Pract Endocrinol Metab 2007 Feb;3(2):92-102.

7. Rana $H Q$, Rainville IR, Vaidya A. Genetic testing in the clinical care of patients with pheochromocytoma and paraganglioma. Curr Opin Endocrinol Diabetes Obes 2014 Jun;21(3):166-176.

8. Eisenhofer G, Lenders JW, Siegert G, Bornstein $\mathrm{SR}$, Friberg $\mathrm{P}$, Milosevic $\mathrm{D}$, et al. Plasma methoxytyramine: a novel biomarker of metastatic pheochromocytoma and paraganglioma in relation to established risk factors of tumour size, location and SDHB mutation status. Eur J Cancer 2012 Jul;48(11):1739-1749.

9. Unger N, Deutschbein T, Walz MK, Mann K, Petersenn S. The value of immunoassays for metanephrines in the biochemical diagnosis of pheochromocytomas. Horm Metab Res 2009 Sep;41(9):676-679.

10. Gumbs AA, Gagner M. Laparoscopic adrenalectomy. Best Pract Res Clin Endocrinol Metab 2006 Sep;20(3):483-499.

11. Conzo G, Musella M, Corcione F, De Palma M, Ferraro F, Palazzo A, et al. Laparoscopic adrenalectomy, a safe procedure for pheochromocytoma. A retrospective review of clinical series. Int J Surg 2013;11(2):152-156.

12. AssaliaA, Gagner M. Laparoscopic adrenalectomy. Br J Surg 2004 Oct;91(10):1259-1274. 